\title{
Corrigendum
}

\section{Educational Inequality, Educational Expansion and Intergenerational Mobility - CORRIGENDUM}

\author{
JO BLANDEN AND LINDSEY MACMILLAN
}

doi:10.1017/So04727941600026X, first published online by Cambridge University Press, 4 May 2016.

Within the original published article the acknowledgements section was sadly omitted. The following acknowledgement should have been included;

\section{Acknowledgements}

This work was part of the Social Policy in a Cold Climate Project at the Centre for the Analysis of Social Exclusion (CASE) at the London School of Economics. This was funded by the Nuffield Foundation, the Joseph Rowntree Foundation and the Trust for London. The views expressed in this article are those of the authors and not necessarily those of the funders. We would like to thank colleagues at CASE, particularly Howard Glennerster, Ruth Lupton and John Hills, for comments on earlier versions of this work. We are also grateful for the suggestions from two reviewers, which have helped to improve this paper further.

\section{Reference}

Blanden, J. and Macmillan, L. (2016), 'Educational Inequality, Educational Expansion and Intergenerational Mobility'. Journal of Social Policy, first published online 4 May 2016 doi:10.1017/So04727941600026X. 